\title{
Antioxidant potential of Cydonia oblonga Miller leaves
}

\author{
Deniz Çıkla Yılmaz*, Serap Ayaz Seyhan \\ Department of Analytical Chemistry, Faculty of Pharmacy, Marmara University, 34668 İstanbul, Turkey
}

Cite this article as: Çıkla Yılmaz D, Ayaz Seyhan S (2017). Antioxidant potential of Cydonia oblonga Miller leaves. Istanbul J Pharm 47 (1): 9-11.

\begin{abstract}
Objective of this study was to determine the total polyphenol content, antioxidant activity properties of the methanolic, ethanolic and aqueous extracts of Cydonia oblonga Miller leaves. Quince leaves have been used as folk medicine in Turkey. Total polyphenol content was determined by Folin-Ciocalteu assay. The antioxidant capacity was determined by ferric ion reducing antioxidant power method (FRAP) and DPPH (2, 2-diphenyl-1 picryl hydrazyl) free radical scavenging method by spectrophotometry. The methanol extract had the highest total phenolic content and the highest antioxidant activity. The results demonstrated that the correlation between total polyphenol content and antioxidant activity which was measured by DPPH and FRAP assays was positive and quince leaves are cheap and natural sources of antioxidants.
\end{abstract}

Keywords: Cydonia oblonga Miller, quince leaves, Folin-Ciocalteu, DPPH

\section{INTRODUCTION}

Nowadays, it is commonly recognized that there is a positive relationship between a diet rich in herbal foods and a reduced incidence of degenerative diseases such as cancer and cardiovascular events. The protection provided against those illnesses has been attributed to a variety of antioxidant compounds, since free radicals present in human organism can cause oxidative damage to several molecules, such as lipids, proteins and nucleic acids, being involved in the initiation of those diseases (Pacifico et al., 2012). Hence, the search for new sources of natural antioxidants is currently of major interest to scientists. Health benefits of quince are known from ancient times. Quince (Cydonia oblonga Miller, Rosaceae family) is found especially in West Anatolia however it is cultivated widely in our country (Davis, 1972). The plant has been used in Turkish folk medicine for treatment of variety of diseases. The leaves are used as antitussive in the form of herbal tea and the fruits with high nutrient value are used for the treatment of diarrhea (Tuzlacı, 2006).

Study of Teleszko \& Wojdylo, 2015 showed that, leaves of well-known crops and wild growing plants contain significantly higher polyphenol compounds than the fruits. In literature application of quince leaves was reported for wool fibers dyeing (Cerempei et al., 2016). There is great number of methods for determination of antioxidant capacity. The DPPH method is rapid, simple, accurate and inexpensive assay for measuring the ability of different compounds to act as free radical scavengers or hydrogen donors, and to evaluate the antioxidant activity of foods and beverages (Marinova \& Batchvarov, 2011). In this study, leaves of the plant were extracted by using various solvents (water, methanol, ethanol) at $60^{\circ} \mathrm{C}$ and evaluated for their antioxidant activity using DPPH and FRAP modified methods. In addition, total phenolic content was determined by Folin-Ciocalteu reagent modified method (S. Ayaz Seyhan et al., 2013).

\section{MATERIALS AND METHODS}

\section{Plant materials}

The quince (Cydonia oblonga Miller) leaves were collected in İstanbul, Turkey. The plant has been identified by Dr. Gizem Bulut from Department of Pharmaceutical Botany, Faculty of Pharmacy, Marmara University. The voucher specimen is kept in Herbarium of the Faculty of Pharmacy, Marmara University (MARE 17527). 


\section{Chemicals}

1,1-Diphenyl-2-picrylhydrazyl radical (DPPH);6-hydroxy-2,5,7,8tetramethylchroman-2-carboxylic acid (Trolox); 2,4,6-tri(2-pyridyl)s-triazine (TPTZ), Folin-Ciocalteu phenol reagent, gallic acid (GA), Trolox (6-hydroxy-2,5,7,8-tetramethylchroman-2-carboxylic acid) were purchased from Sigma-Aldrich (Steinheim, Germany). The rest of chemicals, including sodium carbonate, sodium hydroxide, ferric chloride, methanol, hydrochloric acid, acetic acid were of analytical grade and obtained from Merck. Double distilled water was produced by a Milli-Q System (Millipore, Billerica, MA, USA).

\section{Preparation of plant extracts}

The quince (Cydonia oblonga Miller) leaves materials were dried at the room temperature and ground into fine powders using domestic blender. For antioxidant capacity methods, $1 \mathrm{~g}$ powdered quince leaves were subsequently extracted with three different solvents (methanol, ethanol and water) (solvent to leaf ratio 20:1) at $60^{\circ} \mathrm{C}$ for 1 hours and three cycles. Extract was filtered with Whatman blue band filter paper. All concentrations used in this study were calculated from dry weight (DW). The extracts prepared in this way were kept at $-18^{\circ} \mathrm{C}$ until being tested.

\section{Determination of total phenolic contents}

Total phenolics of quince (Cydonia oblonga Miller) leaves extracts were determined with Folin-Ciocalteu reagent according to the method of Slinkard \& Singleton (1977), with some modifications by using gallic acid as standard (S. Ayaz Seyhan et al., 2013). Sample solution was diluted with distilled water, Folin-Ciocalteu reagent was added. After vortexing and a 5 min incubation period at $30^{\circ} \mathrm{C}_{1} \mathrm{Na}_{2} \mathrm{CO}_{3}(6.0 \%)$ was added, and the mixture was vortexed and incubated for $30 \mathrm{~min}$. at $30^{\circ} \mathrm{C}$. The absorbance of the reaction mixture was read at 685-760 $\mathrm{nm}$ by spectrophotometer (Shimadzu, UV-1601). The total phenolic content was expressed as microgram of gallic acid equivalent (GAE) per $\mathrm{mL}$ sample by using a calibration graph gallic acid concentration range (Figure 1) (Karaçelik et al, 2015; Zengin et al., 2010).

\section{Ferric reducing/antioxidant power (FRAP) assay}

For ferric reducing/antioxidant power (FRAP) assay used in the determination of total antioxidant activities, the improved TPTZ (2,4,6-tris(2-pyridyl)-s-triazine) use is preferred (Benzie and Strain, 1999) with some modifications to accommodate aqueous as well as organic solvent extracts. Quince leaves extract was added to FRAP reagent and the reaction mixture incubated for $30 \mathrm{~min}$. at $37^{\circ} \mathrm{C}$. The increase in the absorbance at 580-600 nm was measured. The antioxidant capacity based on the ability to reduce ferric ions of the extract was expressed as $\mu \mathrm{mol}$ trolox equivalents per sample by using a calibration graph Trolox concentration range of dry weight (DW) (Figure 2).

\section{Scavenging activity on DPPH (2,2-diphenyl-1- picrylhydrazyl) radical}

The free radical scavenging activity of plant extracts were determined by using modified DPPH method (S. Ayaz Seyhan et al., 2013). 0,1 mM solution of DPPH in methanol was prepared and the initial absorbance was measured at 515-528 nm. Quince leaves extract was added to DPPH solution and and the reaction mixture incubated for $30 \mathrm{~min}$. at $37^{\circ} \mathrm{C}$. The change in the absorbance was measured. The antioxidant capacity based on the DPPH free radical scavenging ability of the extract was expressed as micromole of Trolox equivalents (TE) per gram sample by using a calibration graph Trolox concentration range of dry weight (DW) (Figure 3).

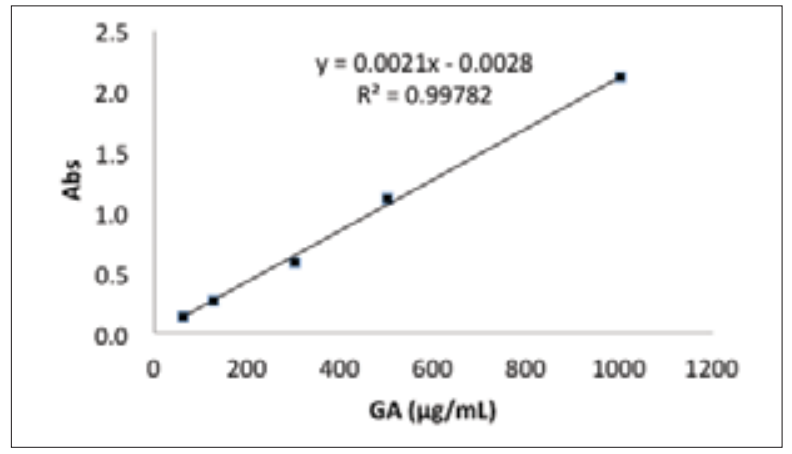

Figure 1. Calibration curve of Gallic acid equivalent by FolinCiocalteau Method

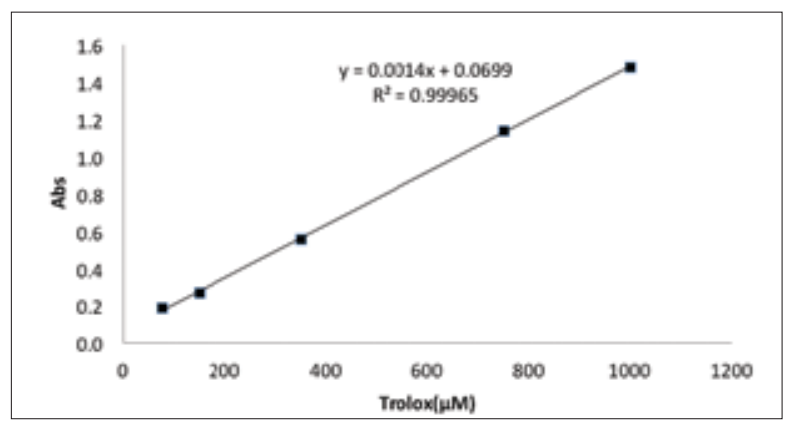

Figure 2. Calibration curve of Trolox equivalent by FRAP Method

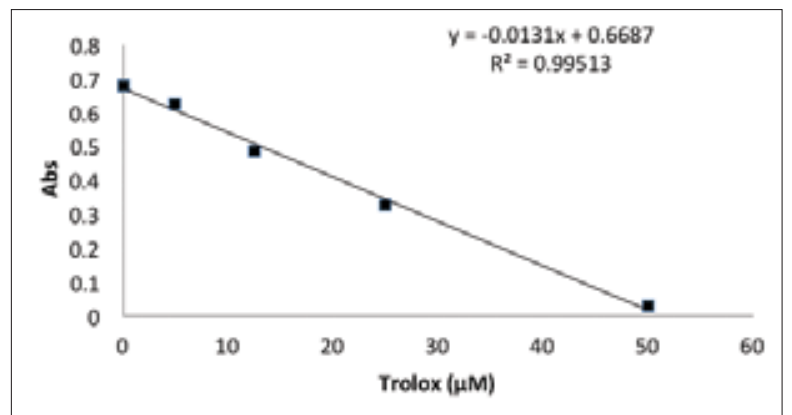

Figure 3. Calibration curve of Trolox equivalent by DPPH Method

\section{RESULTS AND DISCUSSION}

\section{Total phenolic content}

The total phenolic content was calculated using the calibration curve of gallic acid. The Folin-Ciocalteu assay is used to measure total phenolics by an oxidation/reduction (redox) reaction. The principle is based on the transfer of single electrons (SET) in alkaline medium from phenolic compounds to molybdenum to form a blue complex that can be monitored spectrophotometrically at 750-765 nm (Karadag, 2009). Total polyphenols were quantified in the extracts in order to compare the three solvents (methanol, ethanol and water) (Figure 4). The best polyphenol extraction was achieved using methanol. On the contrary, the lowest polyphenol amount was extracted using ethanol as solvent. As indicated in Figure 4, the total polyphenols values varied from 247-744 $\mu \mathrm{g}$ GAE /mL.

\section{Antioxidant capacities}

The antioxidant capacities of samples might be influenced by several factors, such as test system, and could not be fully described 


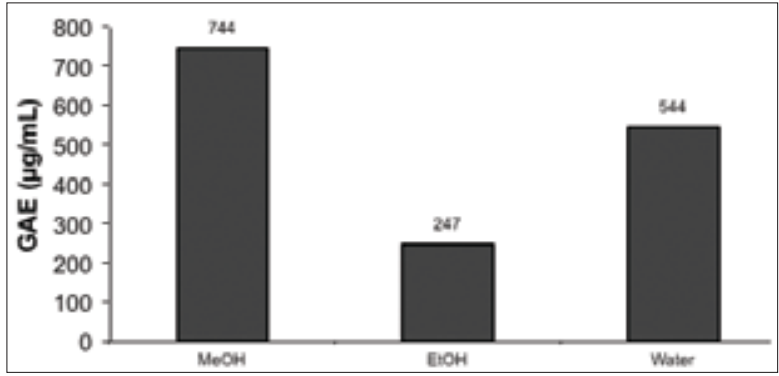

Figure 4. Total polyphenols contents determination of quince leaves extracts by Folin-Ciocalteau method

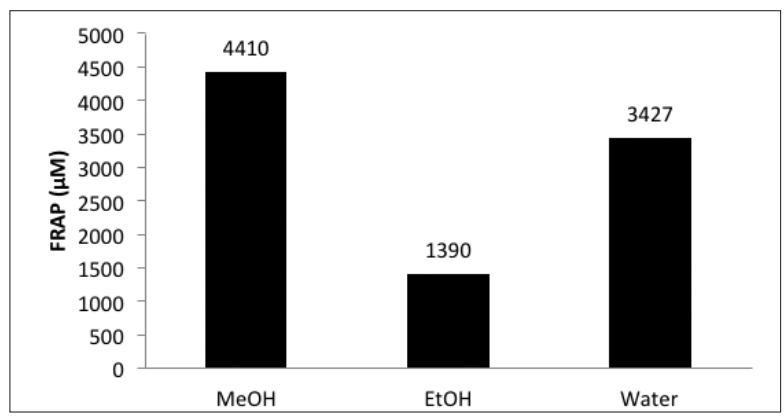

Figure 5. Ferric reducing antioxidant potential assay of quince leaves extracts

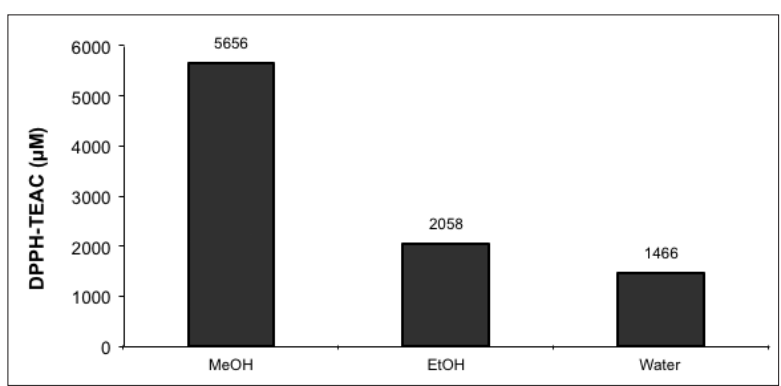

Figure 6. DPPH free radical scavenging assay of quince leaves extracts

by one single method. In addition, most natural antioxidants are multifunctional. Therefore, a reliable antioxidant evaluation protocol requires to perform different antioxidant activity assessments to take into account various mechanisms of antioxidant action (Fu et al., 2011). In this study, the ferric reducing antioxidant power (FRAP) assay was used to evaluate antioxidant capacities of quince (Cydonia oblonga Miller) leaves. The FRAP assay is based on the ability of antioxidant to reduce ferric (III) ions to ferrous(II) ions, which is a simple and widely used method for the evaluation of antioxidant capacity (Karadag A, 2009). The FRAP values of different extraction samples are shown in Figure 5. The best antioxidant capacity was achieved using methanol. The lowest antioxidant capacity was extracted using ethanol as solvent. As indicated in Figure 5, the FRAP values varied from 1390-4410 $\mu \mathrm{M}$ Trolox/mL.

DPPH works in both electron transfer (SET) and hydrogen transfer (HAT) systems and allows the determination of a substance or a complex mixture that donate either hydrogen atoms or electrons in a homogeneous system. DPPH radical can only be dissolved in organic solvents (methanol, ethanol, acetone), which is a limitation when interpreting the role of hydrophilic antioxidants
(Karadag et al., 2009). Several factors may affect the assay such as solvent, $\mathrm{pH}$, sample concentration and reaction time. The DPPH values of difference extraction sample are shown in Figure 6. The best antioxidant capacity was achieved using methanol. On the contrary, the lowest antioxidant capacity was extracted using water as solvent. As indicated in Figure 6, the DPPH values varied from 1466-5656 $\mu \mathrm{M}$ Trolox/mL. DPPH can only be dissolved in organic media (especially in alcoholic media), not in aqueous media, which is an important limitation when interpreting the role of hydrophilic antioxidants. It was concluded that above a certain limit of water content of solvent, the antioxidant capacity decreased, since a part of the DPPH coagulates and it is not easily accessible to the reaction with antioxidants.

The results of this study indicated that methanolic extract of quince (Cydonia oblonga Miller) leaves have higher antioxidant properties compared to ethanolic and aqueous extract. Therefore, they could be considered as complementary raw material in fruit processing, enriching products (e.g. drinks) in bioactive compounds in the future. Further investigation needs to be performed for identification and quantification phenolic compounds present in the quince leaves.

\section{REFERENCES}

- $\quad$ Benzie IF, Strain JJ (1999). Ferric reducing/antioxidant power assay: direct measure of total antioxidant activity of biological fluids and modified version for simultaneous measurement of total antioxidant power and ascorbic acid concentration. Methods Enzymol 299: 15-27. [CrossRef]

- Cerempei A, Mureşan El, Cimpoeşu N, Carp-Carare C, Rimbu C (2016). Dyeing and antibacterial properties of aqueous extracts from quince (Cydonia oblonga) leaves. Ind Crops Prod 94: 216-225. [CrossRef]

- Davis PH (1972). Flora of Turkey and East Aegean Islands. Vol. 4. Edinburgh University Press, Edinburgh, pp. 157.

- Fu L, Xu B, Xu X, Gan R, Zhang Y, Xia E, Li H (2011). Antioxidant capacities and total phenolic contents of 62 fruits. Food Chem 129: 345-350. [CrossRef]

- $\quad$ Karaçelik AA, Küçük M, İskefiyeli Z, Aydemir S, De Smet S, Miserez $B$, Sandra P (2015). Antioxidant components of Viburnum opulus L. determined by on-line HPLC-UV-ABTS radical scavenging and LCUV-ESI-MS methods. Food Chem 175: 106-114. [CrossRef]

- Marinova G, BatchvarovV (2011). Evaluation of the methods for determination of the free radical scavenging activity by DPPH. Bulg J Agric Sci 17: 11-24.

- $\quad$ Pacifico S, Gallicchio M, Fiorentino A, Fischer A, Meyer U, Stintzing FC (2012). Antioxidant properties and cytotoxic effects on human cancer cell lines of aqueous fermented and lipophilic quince (Cydonia oblonga Mill.) preparations. Food Chem Toxicol 50: 4130-4135. [CrossRef]

- Ayaz Seyhan S, Yalçın G, Çıkla Yılmaz D, Demirbağ Ç (2013). Türkiye'de yetişen nar, yaban mersini ve ürünlerinde antioksidan kapasite tayini ve yöntemlerin kromatografik olarak incelenmesi (SAG-A-131113-0423). Prepared for Marmara University BAPKO Projects, İstanbul.

- $\quad$ Slinkard K, Singleton VL (1977). Total phenol analysis: Automation and comparison with manual methods. Am J Enol Vitic 28: 49-55.

- Teleszko M, Wojdylo A (2015). Comparison of phenolic compounds and antioxidant potential between selected edible fruits and their leaves. J Funct Foods 14: 736-746. [CrossRef]

- Tuzlacı E (2006). Şifa Niyetine Türkiye'nin Bitkisel Halk Ilaçları. Alfa Yayınları, İstanbul, pp. 91-93.

- Zengin G, Çakmak YS, Aktümsek A (2010). In vitro antioxidant capacities and fatty acid compositions of three Centaurea species collected from Central Anatolia region of Turkey. Food Chem Toxicol 48: 2638-2641. [CrossRef]

- Karadag A, Ozcelik B, Saner S (2009). Review of methods to determine antioxidant capacities. Food Anal Method 2: 41-60. [CrossRef] 